\title{
Degradation of Cry1Ab protein from genetically modified maize (MON810) in relation to total dietary feed proteins in dairy cow digestion
}

\author{
Vijay Paul • Patrick Guertler • \\ Steffi Wiedemann · Heinrich H. D. Meyer
}

Received: 29 May 2009/ Accepted: 16 October 2009/Published online: 4 November 2009

(C) The Author(s) 2009. This article is published with open access at Springerlink.com

\begin{abstract}
To investigate the relative degradation and fragmentation pattern of the recombinant Cry $1 \mathrm{Ab}$ protein from genetically modified (GM) maize MON810 throughout the gastrointestinal tract (GIT) of dairy cows, a 25 months GM maize feeding study was conducted on 36 lactating Bavarian Fleckvieh cows allocated into two groups (18 cows per group) fed diets containing either GM maize MON810 or nearly isogenic non-GM maize as the respective diet components. All cows were fed a partial total mixed ration (pTMR). During the feeding trial, 8 feed (4 transgenic (T) and 4 non-transgenic (NT) pTMR) and 42 feces (26 $\mathrm{T}$ and $18 \mathrm{NT}$ ) samples from the subset of cows fed T and NT diets, and at the end of the feeding trial, digesta contents of rumen, abomasum, small intestine, large intestine and cecum were collected after the slaughter of six cows of each feeding group. Samples were analyzed for Cry1Ab protein and total protein using CrylAb specific ELISA and bicinchoninic acid assay, respectively. Immunoblot analyses were performed to evaluate the integrity of Cry $1 \mathrm{Ab}$ protein in feed, digesta and feces samples. A decrease to $44 \%$ in Cry $1 \mathrm{Ab}$ protein concentration from T pTMR to the voided feces $(9.40$
\end{abstract}

V. Paul · P. Guertler $\cdot$ S. Wiedemann .

H. H. D. Meyer ( $₫)$

Physiology Weihenstephan, Technische Universitaet

Muenchen, Weihenstephaner Berg 3, 85350 Freising,

Germany

e-mail: hhdmeyer@wzw.tum.de versus $4.18 \mu \mathrm{g} / \mathrm{g}$ of total proteins) was recorded. Concentrations of Cry1 Ab protein in GIT digesta of cows fed T diets varied between the lowest $0.38 \mu \mathrm{g} / \mathrm{g}$ of total proteins in abomasum to the highest $3.84 \mu \mathrm{g} / \mathrm{g}$ of total proteins in rumen. Immunoblot analysis revealed the extensive degradation of recombinant Cry $1 \mathrm{Ab}$ protein into a smaller fragment of around $34 \mathrm{kDa}$ in GIT. The results of the present study indicate that the recombinant $\mathrm{Cry} 1 \mathrm{Ab}$ protein from MON810 is increasingly degraded into a small fragment during dairy cow digestion.

Keywords Cry1 Ab protein - Dairy cow · Genetically modified maize MON810 - Digesta

\section{Introduction}

Genetically modified (GM) maize MON810, expressing the insecticidal Cry1 Ab protein, has been approved as an animal feed in several countries worldwide. Already many studies on GM feeds have been documented regarding animal performance and health, as well as resultant food safety [reviewed by (Flachowsky et al. 2005; Report of the EFSA GMO panel working group on Animal feeding trials 2008)]. The previous studies (Chowdhury et al. 2003; Einspanier et al. 2004; Lutz et al. 2005) on the digestive fate of Cry1 $\mathrm{Ab}$ protein from GM maize (events: Bt11 and Bt176) in ruminant gastrointestinal 
tract (GIT) revealed that the recombinant protein is degraded during digestion. However, there is no information available on the in vivo digestive fate of transgenic protein from MON810 in relation to other dietary feed proteins in ruminants.

In ruminants, a very special way of digestion exists for the breakdown of ingested feed material in the GIT. Unlike other mammals, ruminants have a fourchambered (rumen, reticulum, omasum and abomasum) stomach that is specially designed for the fermentation of dietary carbohydrates and proteins. The digestion process begins in rumen, using the microorganisms to breakdown the complex feed particles into simple sugar and volatile fatty acids. The fermented digesta from rumen passes in small amounts into the next chamber reticulum. From the reticulum the small packets of ingested food passes back into the mouth for chewing. The re-chewed food is then swallowed and passed into the omasum. The food in omasum is broken down into even smaller pieces by powerful muscular movements. After spending some time in the omasum, the food passes to the abomasum. In the abomasum, food is broken down by the digestive enzymes, particularly by the lysozymes. The digested food then passes into the small intestine, large intestine and finally undigested feed material is voided as feces. In intestine water from digesta is removed and nutrients are absorbed into blood streams.

In general, dietary proteins are broken down to decreasingly smaller fragments under the influence of a sequence of processes that occur in different segments of the GIT of ruminants. These processes include fermentation of dietary components by microbes during incubation in the reticulo-rumen, acid hydrolysis and degradation by enzymes of the host animal in the abomasum and small intestine, and secondary fermentation in the cecum and large intestine. Most of the ingested feed proteins are degraded by 40 to $80 \%$ of their initial amounts in the rumen and utilized by rumen microbes for the synthesis of microbial protein [as reviewed by (Chalupa 1975)]. However, maize proteins are relatively resistant to the ruminal degradation (Romagnolo et al. 1994). Also the site of digestion affects the nature of absorbed end-products and the extent of nutrient losses occurring during digestion. Thus, the objective of the present study was to determine stability or degradation of the Cry $1 \mathrm{Ab}$ protein relative to total dietary proteins in feed, GIT digesta and feces of dairy cows.

\section{Materials and methods}

All animal handling and experimentation were conducted under the approval of the Bavarian State Research Center (LfL, Grub, Germany) institutional animal care and use committee. To investigate the digestive fate of recombinant $\mathrm{Cry} 1 \mathrm{Ab}$ protein from genetically modified (GM) maize MON810 in dairy cow digestion, thirty-six Bavarian Fleckvieh cows were separated into a "transgenic" group $(n=18$, nine primiparous and nine multiparous) fed on a diet containing GM maize MON810 and a control or "nontransgenic" group ( $n=18$, nine primiparous and nine multiparous) fed conventional maize over a period of 25 months. All experimental cows were apparently healthy with the body condition score ranging from 3.3 to 3.9. Cows were housed at the Bavarian State Research Center and fed a partial total mixed ration (pTMR). The diet composition is shown in Table 1. According to the milk yield further concentrates [40.4\% maize kernels (transgenic or non-transgenic based on respective diets), $34.4 \%$ rapeseed meal, $19.9 \%$ molasses dried beet pulp, $3.2 \%$ mineral mixture and $2.4 \%$ urea] were offered above $22 \mathrm{~kg}$ milk yield per day. For pTMR preparation, GM maize MON810 and the non-transgenic variety had been cultivated and

Table 1 Ingredients and composition of the partial total mixed ration

\begin{tabular}{lc}
\hline Ingredient & Ratio (DM basis) (\%) \\
\hline Maize silage $^{\mathrm{a}}$ & 41.9 \\
Maize cobs $^{\mathrm{a}}$ & 21.2 \\
Grass silage & 11.0 \\
Straw & 5.9 \\
Molasses & 1.4 \\
Concentrates & 18.6 \\
Rapeseed meal & 51.1 \\
Maize kernels & 41.2 \\
Mineral mixture & 5.3 \\
Urea & 2.4 \\
\hline
\end{tabular}

${ }^{a}$ Ingredients contained 100\% MON810 in transgenic mixed ration and conventional maize in non-transgenic mixed ration diets 
harvested in 2004, 2005 and 2006 under similar agronomic conditions at the Bavarian State Research Center for Agriculture (Germany). Nutrients and energy contents of both maize varieties were comparable, ensuring equivalent feed conditions (data not shown). The details of the animal management and sample collection are given somewhere else (Steinke et al. 2009; Guertler et al. 2009a, b).

To evaluate the digestive fate of recombinant $\mathrm{Cry} 1 \mathrm{Ab}$ protein during the feeding trial, four samples of each diet (transgenic and non-transgenic maize kernel, cobs, silage, and pTMR) and forty-two feces samples (26 transgenic and 18 non-transgenic) were collected from the subset of cows. To determine the amount and fragmentation pattern of Cry1 Ab protein in the GIT digesta, contents of rumen, abomasum, small intestine, large intestine and cecum were collected after the slaughter of six cows of each feeding group at the end of the feeding trial. All samples were stored at $-80^{\circ} \mathrm{C}$ until analyzed for total protein and Cry1 Ab protein.

All feed samples were finely ground in liquid nitrogen using mortar and pestle. Total proteins were extracted from the pulverized feed $(100 \mathrm{mg})$, feces $(100 \mathrm{mg})$ and GIT digesta $(200 \mathrm{mg})$ samples after the homogenization with $1 \mathrm{ml}$ ice-cold extraction buffer (PBST; $8 \mathrm{mM}$ sodium phosphate, $137 \mathrm{mM} \mathrm{NaCl}$, $2.7 \mathrm{mM} \mathrm{KCl}, 1.5 \mathrm{mM}$ potassium phosphate, $0.1 \%$

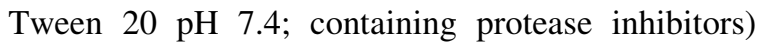
using $300 \mathrm{mg}$ matrix green ceramic beads in a Fastprep homogenization machine. The supernatants were collected in $1.5 \mathrm{ml}$ microcentrifuge tubes after centrifugation at $15,000 \times g$ at $4^{\circ} \mathrm{C}$ for $15 \mathrm{~min}$. A clear extract was collected after re-centrifugation at $15,000 \times g$ at $4^{\circ} \mathrm{C}$ for $10 \mathrm{~min}$ and stored at $-20^{\circ} \mathrm{C}$ until used for total protein and $\mathrm{Cry} 1 \mathrm{Ab}$ protein quantification.

Total protein concentration in each extract was measured by bicinchoninic acid (BCA) assay (Smith et al. 1985) using BSA as protein standard. For determination of the Cry1 $\mathrm{Ab}$ protein concentration, a previously developed sandwich ELISA (Paul et al. 2008) was used under slight modifications and matrix specific assay validations (Guertler et al. 2009a, b). Briefly, an assay was performed on Cry1 $\mathrm{Ab}$ protein affinity purified specific antibody coated 96-well microtiter plates by incubating $50 \mu$ of sample extract or Cry $1 \mathrm{Ab}$ protein standards (HPLC-purified trypsinactivated $\mathrm{Cry} 1 \mathrm{Ab}$ protein calibrator concentrations ranging from 2 to $1,000 \mathrm{pg}$ per $50 \mu \mathrm{l}$ extraction buffer) along with $100 \mu \mathrm{l}$ assay buffer (PBST containing $0.1 \% \mathrm{BSA}$ ). After overnight incubation at 6 to $8^{\circ} \mathrm{C}$, plates were washed six-times with $300 \mu \mathrm{l}$ PBST per well. The amount of antibody captured Cry1 Ab protein from samples/standards was measured by applying a biotin labeled Cry1 Ab specific antibody, streptavidin-peroxidase enzyme conjugate and 3,3' $, 5,5^{\prime}$-tetramethylbenzidine (TMB) substrate reaction. Cry $1 \mathrm{Ab}$ protein concentrations in unknown samples were interpreted from the Cry $1 \mathrm{Ab}$ protein calibration curve generated using online software Magellan 6 (Tecan, Austria). The concentrations were finally presented as $\mu \mathrm{g}$ Cry $1 \mathrm{Ab}$ protein per $\mathrm{g}$ total protein and ng Cry1 Ab protein per g wet sample.

To monitor the fragmentation of Cry $1 \mathrm{Ab}$ protein from MON810 in transgenic feed, GIT digesta and feces immunoblot analyses were performed. Total protein $(60 \mu \mathrm{g}$ total protein or $100 \mathrm{pg}$ Cry $1 \mathrm{Ab}$ protein extracts from $\mathrm{T}$ feed and feces or respective equivalent amount of total protein from NT feed and feces) of transgenic and non-transgenic feed, GIT digesta and feces were resolved on 12\% SDS-PAGE and transferred to nitrocellulose membranes (Protran $\mathrm{AB}$ 85, Whatman, Dassel, Germany). Membranes with blotted protein bands were incubated with affinity purified anti-Cry1 Ab protein (rabbit pAb, $0.1 \mu \mathrm{g} / \mathrm{ml}$ ) (Paul et al. 2008) and HRP-labeled polyclonal goat anti-rabbit secondary $(1: 10,000)$ antibody (Santa Cruz biotechnology, Germany). Antibody binding was visualized by chemiluminescence (Supersignal west pico system, Pierces, USA). In immunoblot analysis, a positive control containing HPLC purified trypsin activated Cry1 $\mathrm{Ab}$ protein $(65 \mathrm{kDa})$ was used to confirm and verify the positive presence of Cry $1 \mathrm{Ab}$ protein. Student's $t$-test was used to compare the means of Cry1 $\mathrm{Ab}$ protein concentrations in transgenic feed and feces, and total proteins in GIT digesta of cows fed transgenic and non-transgenic diets. A $P$-value below 0.05 was considered significant.

\section{Results and discussion}

The results of the Cry1 $\mathrm{Ab}$ protein quantification using a validated sandwich ELISA (according to the guidelines cited in European Commission Decision 2002/657/EC) in feed (transgenic and non-transgenic pTMR) and feces samples of cows fed transgenic 
and non-transgenic diets showed a $44 \%$ decrease $(P<0.01)$ in $\mathrm{Cry} 1 \mathrm{Ab}$ protein concentration from transgenic pTMR to feces. The mean levels of Cry1 Ab protein in transgenic feed (pTMR) and feces were 9.40 and $4.18 \mu \mathrm{g}$ Cry $1 \mathrm{Ab}$ protein/g total protein, respectively (Fig. 1a). The corresponding absolute concentrations of Cry1 Ab protein were recorded 245.5 and $57.1 \mathrm{ng} / \mathrm{g}$ wet samples in transgenic feed and feces, respectively (Fig. 1b).Whereas, the corresponding total protein contents in the feces $(13.13 \mathrm{mg} / \mathrm{g}$ wet weight) of cows fed transgenic pTMR were $50 \%$ of the initial levels of the total dietary feed proteins $(26.29 \mathrm{mg} / \mathrm{g}$ fresh weight). Digesta contents of rumen, abomasum, small intestine, large intestine and cecum of cows fed transgenic diets contained $3.84,0.38,0.83,2.89$ and $3.18 \mu \mathrm{g}$ of Cry1 Ab protein/g total protein, respectively (Fig. 2a). The absolute concentrations of Cry1 Ab protein in rumen, abomasum, small intestine, large intestine and cecum content were 11.17, 2.66, 9.4232 .82 , and $35.55 \mathrm{ng} / \mathrm{g}$ digesta, respectively (Fig. 2b). However, the corresponding samples of non-transgenic feed, digesta and feces were found below the assay decision limit $(\mathrm{CC} \alpha)$ value of $1.21 \mathrm{ng}$ Cry $1 \mathrm{Ab}$ protein/g wet weight of the sample. The probable reason for the higher concentration of Cry $1 \mathrm{Ab}$ protein

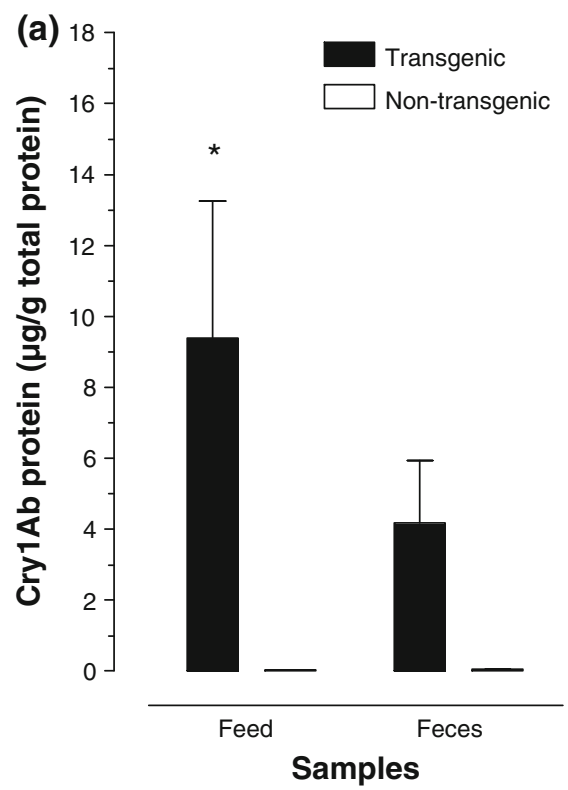

Fig. 1 Concentration of Cry1Ab protein in feed (pTMR) and feces of dairy cows fed partial total mixed rations containing either transgenic maize or non-transgenic maize. Panel, in rumen content could be the existence of relatively large particles of undigested feed and degradation of dietary proteins by rumen microbes. The lowest relative concentration of Cry $1 \mathrm{Ab}$ protein in abomasum could be due to the release of microbial proteins into the abomasum. Further gradual increase in the relative Cry $1 \mathrm{Ab}$ protein concentration in digesta of subsequent segments of the GIT (from abomasum to cecum) could be the due to absorption of end products of protein digestion in the small intestine (amino acids and small peptides) and the removal of water from digesta in large intestine and cecum. The previous reports of feeding ruminants with other GM maize events; Bt11 (Chowdhury et al. 2003) and Bt176 (Einspanier et al. 2004; Lutz et al. 2005) have shown a similar degradation pattern of recombinant Cry $1 \mathrm{Ab}$ protein in the bovine GIT. The concentrations of Cry $1 \mathrm{Ab}$ protein measured in transgenic feed, digesta and feces in the present investigation differ to those reported in these earlier studies, however, a similar trend of $0.25,0.75,0.32,0.11,0.63,0.22$ and $0.08 \mathrm{ng}$ immunoreactive Cry $1 \mathrm{Ab}$ protein/g total protein was reported by Einspanier et al. 2004 in Bt176 maize, rumen retant, rumen eluat, abomasum juice, jejunum juice, colon juice and feces of Bt176 fed cattle. Another study (Lutz et al. 2005) also

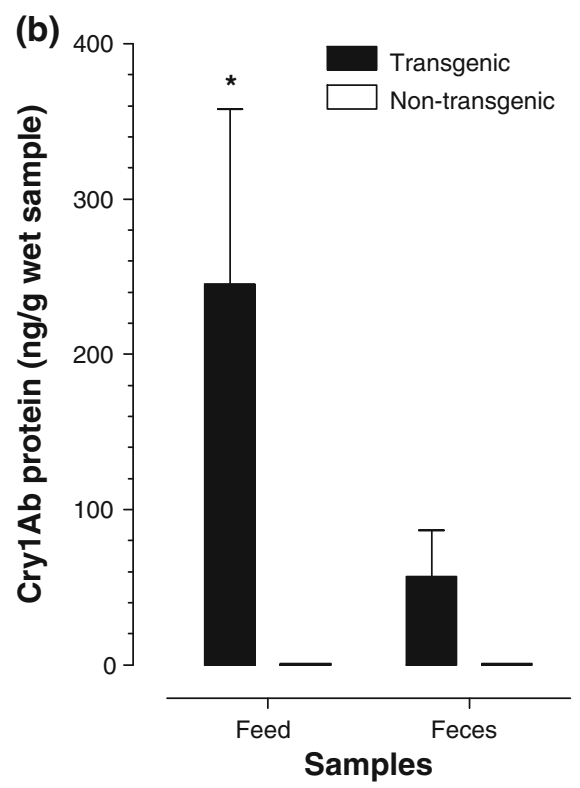

a represents Cry $1 \mathrm{Ab}$ protein $\mu \mathrm{g} / \mathrm{g}$ total protein, and $\mathbf{b}$ represents $\mathrm{Cry} 1 \mathrm{Ab}$ protein $\mathrm{ng} / \mathrm{g}$ wet sample, respectively asterisks indicates $(P<0.01)$ 


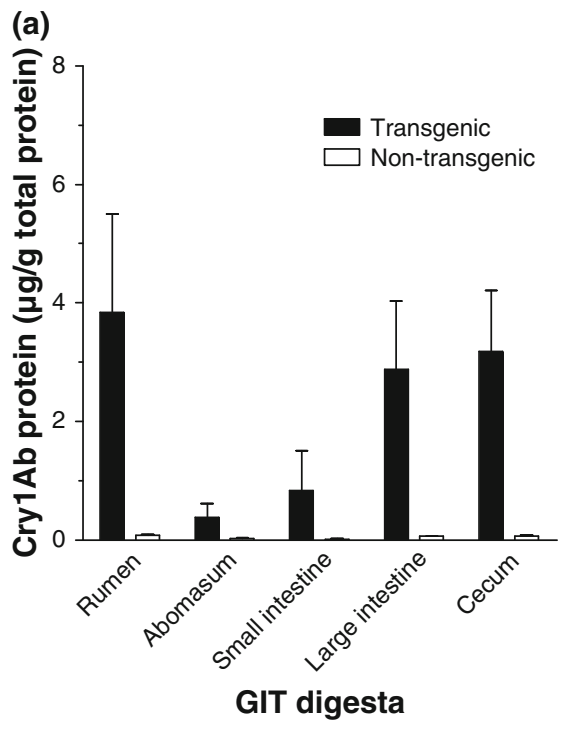

Fig. 2 Relative Cry1Ab protein concentrations in different GIT digesta for cows fed a partial total mixed ration diets containing either transgenic or non-transgenic maize. Panel, a represents Cry $1 \mathrm{Ab}$ protein $\mu \mathrm{g} / \mathrm{g}$ total protein, and $\mathbf{b}$ represents

reported the similar trend of 5.1, 1.4, 3.8 and $4.4 \mathrm{ng}$ Cry1 Ab protein/g wet sample in digesta content of rumen, jejunum, colon and feces of Bt176 fed lactating cows. Whereas, a Bt11 maize feeding study (Chowdhury et al. 2003) on calves suggested that only a trace amount of Cry $1 \mathrm{Ab}$ protein survived the passage through the GIT. The reason for these differences in concentrations could be the different expression levels of recombinant protein in GM maize events (Bt11, Bt176 and MON810) as well as the different physiological and metabolic status of the experimental animals. The total protein concentrations showed a rising trend during the passage of the ingesta from rumen to cecum in the bovine GIT (Fig. 3). However, no effect of two different diets (transgenic and non-transgenic) was observed on the total protein concentrations throughout the GIT. The results of immunoblot analysis for recording the fragmentation pattern of $\mathrm{Cry} 1 \mathrm{Ab}$ protein from MON810 in transgenic feed, GIT digesta and feces revealed the degradation of full-sized $(65 \mathrm{kDa})$ recombinant protein into smaller immunoactive fragments of approximately 42, 34 and $17 \mathrm{kDa}$ (Figs. 4, 5, 6). Fragments of $42 \mathrm{kDa}$ were present only in the transgenic feed (kernel, cobs and pTMR). The most prominent immunoactive fragment observed in all transgenic feed, digesta and feces

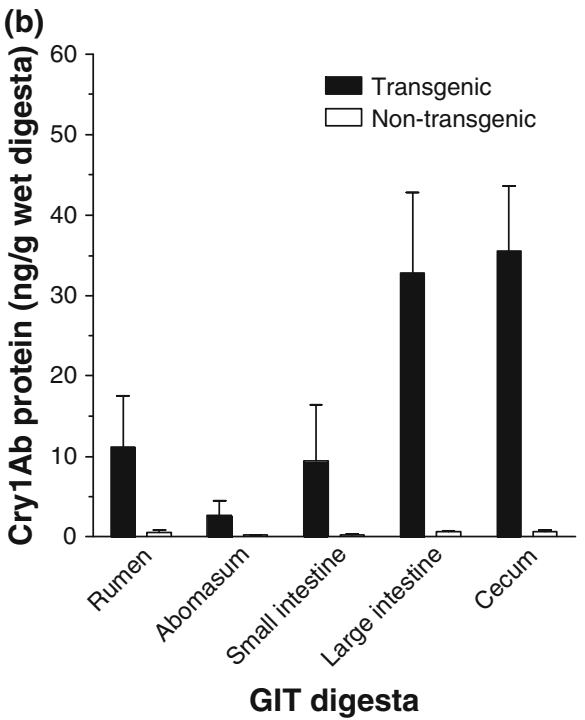

Cry1 Ab protein ng/g digesta, respectively. Concentrations of $\mathrm{Cry} 1 \mathrm{Ab}$ protein in non-transgenic diet fed digesta were below the assay decision limit $(\mathrm{CC} \alpha)$ value of $1.21 \mathrm{ng} / \mathrm{g}$ wet weight

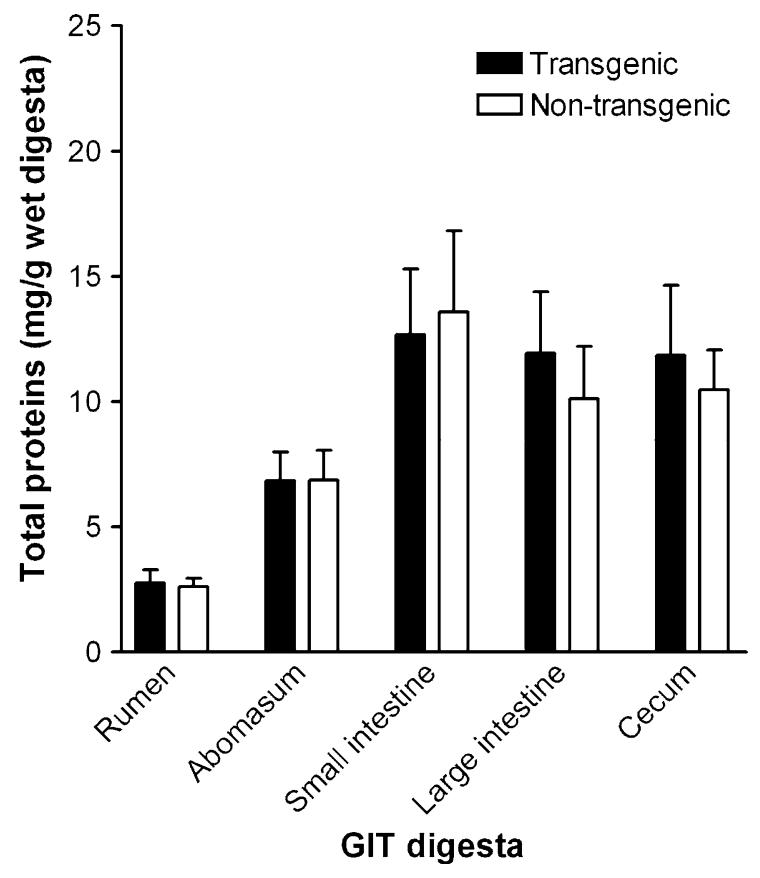

Fig. 3 Relative total protein concentrations in different GIT digesta for cows fed a partial total mixed ration containing either transgenic or non-transgenic maize

was $34 \mathrm{kDa}$. Weak signals of a $17 \mathrm{kDa}$ fragment were recorded in transgenic feed (kernel and cobs) and digesta (cecum). The probable reasons for the 


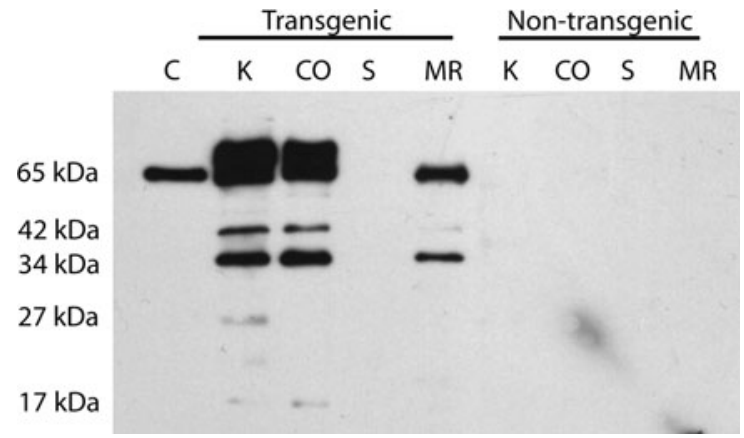

Fig. 4 Western blot showing fragments of Cry $1 \mathrm{Ab}$ protein in total protein extracts $(60 \mu \mathrm{g})$ of transgenic and non-transgenic diet ingredients $(K$, kernels; $C O$, cobs; $S$, silage; $M R$, partial total mixed ration). Trypsin treated and HPLC purified Cry $1 \mathrm{Ab}$ protein $(100 \mathrm{pg})$ was included as a positive control $(C)$

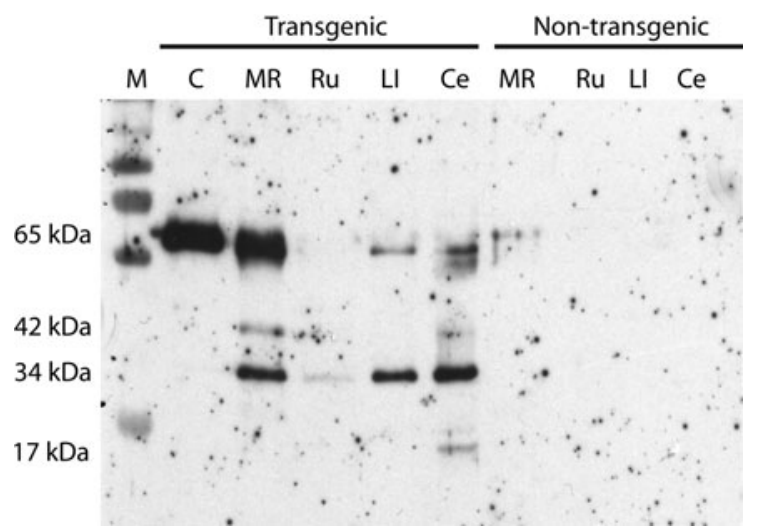

Fig. 5 Western blot showing fragments of Cry $1 \mathrm{Ab}$ protein in GIT digesta ( $R u$, rumen; $L I$, large intestine; $C e$, cecum) extracts from transgenic and non-transgenic diets $(M R)$ fed cows. Trypsin treated and HPLC purified Cry1 Ab protein (100 pg) was included as a positive control $(C)$. Each extract except rumen content contained $100 \mathrm{pg}$ Cry1 Ab protein (as measured in ELISA), whereas due to low concentration of Cry1 Ab protein in rumen content extract $70 \mathrm{pg}$ Cry1 $\mathrm{Ab}$ protein was used. In non-transgenic feed and digesta extract respective amount of total protein was used

degradation of recombinant Cry1 Ab protein are feed processing and storage, and microbial and enzymatic proteolysis in ruminant digestive tract. The previous reports (Lutz et al. 2005, 2006; Wiedemann et al. 2006) of recombinant protein degradation from other GM maize (Bt176) in bovine GIT correspond with our present findings. The presence of a single $34 \mathrm{kDa}$ fragment in feces could be attributed to the timedependent degradation of Cry $1 \mathrm{Ab}$ protein in rumen as suggested by the in situ degradation study on Cry $1 \mathrm{Ab}$

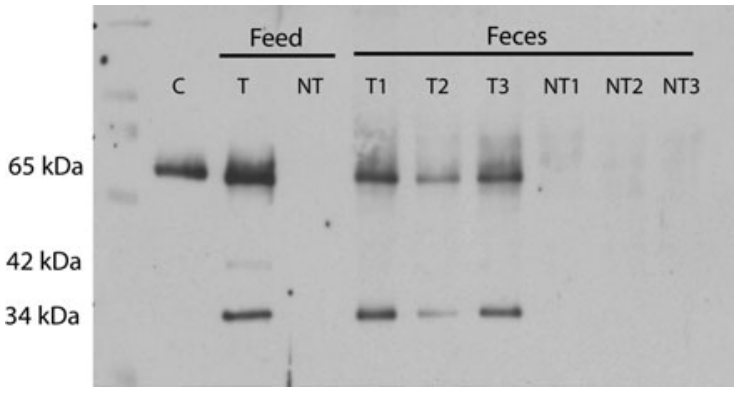

Fig. 6 Western blot showing Cry1 Ab protein fragments in total protein extracts $(60 \mu \mathrm{g})$ of transgenic $(T)$ and nontransgenic feed $(N T)$ and respective transgenic $(T 1, T 2, T 3)$ and non-transgenic (NT1,NT2, NT3) ration fed feces of dairy cows. Trypsin treated and HPLC purified Cry1 Ab protein (100 pg) was used as a positive control (C)

protein in bovine rumen (Wiedemann et al. 2006). In the present study we could not detect any band of $\mathrm{Cry} 1 \mathrm{Ab}$ protein and its fragments in transgenic silage, abomasal and small intestine digesta due to the low concentration (below the detection limit of $100 \mathrm{pg}$ $\mathrm{Cry} 1 \mathrm{Ab}$ protein for immunoblots) of recombinant protein in these samples.

In conclusion, the results of the present study indicate that $\mathrm{Cry} 1 \mathrm{Ab}$ protein from MON810 is increasingly degraded during dairy cow digestion via small fragments of $42 \mathrm{kDa}, 34 \mathrm{kDa}$ and $17 \mathrm{kDa}$. In comparison with total protein in feed, the relative amount of Cry1 Ab protein in feces is markedly reduced indicating that $\mathrm{Cry} 1 \mathrm{Ab}$ protein is not more stable than other proteins in the feed.

Acknowledgments This study was funded by the Bavarian State Ministry of Nutrition, Agriculture and Forestry. The authors gratefully acknowledge the assistance from staff and colleagues at TUM and Bavarian State Research Center.

Open Access This article is distributed under the terms of the Creative Commons Attribution Noncommercial License which permits any noncommercial use, distribution, and reproduction in any medium, provided the original author(s) and source are credited.

\section{References}

Chalupa W (1975) Rumen bypass and protection of proteins and amino acids. J Dairy Sci 58:1198-1218

Chowdhury EH, Shimada N, Murata H, Mikami O, Sultana P, Miyazaki S, Yoshioka M, Yamanaka N, Hirai N, Nakajima Y (2003) Detection of Cry1 Ab protein in the gastrointestinal contents but not visceral organs of genetically modified Bt11fed calves. Vet Hum Toxicol 43:71-75 
Einspanier R, Lutz B, Rief S, Berezina O, Zverlov V, Schwarz W, Mayer J (2004) Tracing residual recombinant feed molecules during digestion and rumen bacterial diversity in cattle fed transgene maize. Eur Food Res Technol 218:269-273

Flachowsky G, Chesson A, Aulrich K (2005) Animal nutrition with feeds from genetically modified plants. Arch Anim Nutr 59:1-40

Guertler P, Paul V, Albrecht C, Meyer HH (2009a) Sensitive and highly specific quantitative real-time PCR and ELISA for recording a potential transfer of novel DNA and Cry1Ab protein from feed into bovine milk. Anal Bioanal Chem 393:1629-1638

Guertler P, Paul V, Steinke K, Preissinger W, Wiedemann S, Albrecht C, Spiekers H, Schwarz F, Meyer H (2009b) Investigations on the potential transfer of recombinant DNA and Cry1 Ab protein from feed into milk, blood, feces and urine of cows fed genetically modified maize. Proc Soc Nutr Physiol 18:111 (Abstract)

Lutz B, Wiedemann S, Einspanier R, Mayer J, Albrecht C (2005) Degradation of Cry1Ab protein from genetically modified maize in the bovine gastrointestinal tract. J Agric Food Chem 53:1453-1456

Lutz B, Wiedemann S, Albrecht C (2006) Degradation of transgenic Cry1 Ab DNA and protein in Bt-176 maize during the ensiling process. J Anim Physiol Anim Nutr (Berl) 90:116-123
Paul V, Steinke K, Meyer HH (2008) Development and validation of a sensitive enzyme immunoassay for surveillance of Cry1 Ab toxin in bovine blood plasma of cows fed Bt-maize (MON810). Anal Chim Acta 607:106-113

Report of the EFSA GMO panel working group on Animal feeding trials (2008) Safety and nutritional assessment of GM plants and derived food and feed: the role of animal feeding trials. Food Chem Toxicol 46(1):S2-S70

Romagnolo D, Polan CE, Barbeau WE (1994) Electrophoretic analysis of ruminal degradability of corn proteins. J Dairy Sci 77:1093-1099

Smith PK, Krohn RI, Hermanson GT, Mallia AK, Gartner FH, Provenzano MD, Fujimoto EK, Goeke NM, Olson BJ, Klenk DC (1985) Measurement of protein using bicinchoninic acid. Anal Biochem 150:76-85

Steinke K, Paul V, Guertler P, Preissinger W, Wiedemann S, Albrecht C, Spiekers H, Meyer H, Schwarz F (2009) Effects of long-term feeding of genetically modified maize (Bt-maize; MON810) to dairy cows on performance and metabolic parameters. Proc Soc Nutr Physiol 18:110 (Abstract)

Wiedemann S, Lutz B, Kurtz H, Schwarz FJ, Albrecht C (2006) In situ studies on the time-dependent degradation of recombinant corn DNA and protein in the bovine rumen. J Anim Sci 84:135-144 